\title{
Gambaran Karakteristik dan Pengetahuan Ibu Nifas Tentang Post Partum Blues di Klinik Pratama SAM Kecamatan Medan Maimun Tahun 2021
}

\author{
Penulis: \\ Merlina Sinabariba ${ }^{1}$ \\ Desriati Sinaga ${ }^{2}$ \\ Ria Marsalena ${ }^{3}$
}

Afiliasi:

STIKes Santa Elisabeth

Medan $^{1,2,3}$

Korespondensi:

riamarsalena28@gmail.

com

Histori Naskah:

Diajukan: 2021-12-15

Disetujui: 2021-12-15

Publikasi: 2022-01-10

\begin{abstract}
Abstrak:
Post Partum Blues adalah gangguan mood sementara yang terjadi pada hari pertama sampai hari ke-10 setelah persalinan dengan gejala tangisan singkat, perasaan kesepian, cemas, bingung, gelisah, letih, pelupa dan insomnia. Pada penelitian Edward tahun 2017 didapatkan 23\% yang mengalami post partum blues di Indonesia.

Tujuan penelitian ini untuk mengetahui Gambaran Karakteristik dan Pengetahuan Ibu Nifas tentang Post Partum Blues di Klinik Pratama SAM Kecamatan Medan Maimun. Jenis penelitian yaitu bersifat deskriptif atau menggambarkan/mendeskripsikan masalah penelitian tentang pengetahuan ibu nifas terhadap post partum blues. Teknik sampel yang digunakan yaitu Non Probability yaitu total sampling. Sampel dalam penelitian ini yaitu seluruh ibu nifas yang bersalin di Klinik Pratama SAM Kecamatan Medan Maimun Tahun 2021 sebanyak 20 orang, instrumen yang digunakan adalah kuesioner. Pengetahuan responden dalam penelitian ini mayoritas kurang sebanyak 11 responden (55\%), cukup sebanyak 5 responden $(25 \%)$ dan baik sebanyak 4 responden (20\%). Dapat disimpulkan bahwa pengetahuan ibu nifas tentang post partum blues masih kurang. Diharapkan melalui kuesioner yang telah dibagikan, dapat menambah wawasan ibu nifas mengenai post partum blues. Pengetahuan ibu nifas tentang post partum blues mayoritas berpengetahuan kurang sebanyak 11 responden, diharapkan supaya meningkatkan pengetahuan serta mempertahankan pengetahuan yang telah didapatkan dan pengetahuan yang telah di peroleh supaya di terapkan dalam kehidupan sehari-hari tentang bagaimana cara mencegah supaya tidak terjadinya Post Partum Blues pada masa nifas.
\end{abstract}

Kata kunci: Karakteristik, Pengetahuan Ibu Nifas, Post Partum Blues

\section{Pendahuluan}

Masa nifas adalah masa setelah melahirkan selama 6 minggu atau 40 hari menurut hitungan awam merupakan masa nifas. Masa ini penting sekali untuk terus dipantau. Nifas merupakan masa pembersihan rahim, sama halnya seperti masa haid. Jadi secara alamiah rahim akan kembali mengecil perlahan-lahan kebentuknya semula. Setelah 6 minggu beratnya sudah sekitar 40-60 gram. Pada saat ini dianggap bahwa masa nifas sudah selesai. Namun, sebenarnya rahim akan kembali keposisinya yang normal dengan berat 30 gram dalam waktu 3 bulan setelah masa nifas. Selama masa pemulihan 3 bulan ini, bukan hanya rahim saja yang kembali normal, tapi juga kondisi ibu secara keseluruhan. Proses ovulasi uterus disertai dengan penurunan tinggi fundus uteri. Pada hari pertama, TFU di atas simfisis pubis atau sekitar $12 \mathrm{~cm}$. (Yuanita Viva, 2020) 
Periode setelah melahirkan, ibu mengalami perubahan fisik dan psikologis. Ibu merasa bahagia yang luar biasa, dan melakukan eksplorasi dan penyesuaian terhadap bayinya, akan tetapi juga terdapat beban untuk menyerap pembelajaran tentang perawatan bayinya dan merasa ini adalah tanggung jawab yang luar biasa sebagai seorang ibu. Tekanan psikologis pada masa postpartum relative tinggi, diperkirakan 13-19\% ibu mengalami depresi postpartum dan 1,5-5,6\% ibu mengalami stress pascatrauma. Post partum blues, maternity blues atau baby blues merupakan gangguan mood/afek ringan sementara yang terjadi pada hari pertama sampai hari ke-10 setelah persalinan. Post partum blues biasanya terjadi pada hari ketiga atau keempat post partum dan memuncak antara hari kelima dan ke-14 post partum yang ditandai dengan tangisan singkat, perasaan kesepian atau ditolak, cemas, bingung, gelisah, letih, pelupa dan tidak dapat tidur. (Pebri Warita Pulungan, 2020).

Riset menunjukkan $10 \%$ ibu mengalami depresi setelah melahirkan dan 10\%-nya saja yang tidak mengalami perubahan emosi. Keadaan ini berlangsung antara 3-6 bulan bahkan pada beberapa kasus terjadi selama 1 tahun pertama kehidupan bayi. Penyebab depresi terjadi karena reaksi terhadap rasa sakit yang muncul saat melahirkan dan karena sebab-sebab yang kompleks lainnya. (Susilo Rini \& Feti Kumala, 2017). Post Partum Blues (PBB) menurut Sri Wahyuningsih \& Mahasiswi D3. Menurut data salah satu peneliti gejala yang paling sering dialami adalah $48 \%$ sedih, $23 \%$ menangis, $41 \%$ mudah tersinggung, $41 \%$ cemas, $26 \%$ labilitas perasaan, $15 \%$ gangguan tidur dan $21 \%$ gangguan nafsu makan.

Cakupan pelayanan kesehatan ibu nifas lengkap (KF3) di Provinsi Sumatera Utara tahun 2018 sebesar $82,23 \%$. Bila dibandingkan dengan target yang ditetapkan dalam Renstra Dinas Kesehatan Provinsi Sumatera Utara untuk tahun 2018 sebesar 83\%, maka cakupan ini sudah mendekati target yang sudah ditetapkan. Cakupan pelayanan ibu nifas (KF3) tertinggi ada di Kabupaten Langkat (93,69\%), Kabupaten Tapanuli Selatan (93,05\%), dan Kabupaten Batubara (92,61\%). Sedangkan cakupan pelayanan ibu nifas (KF3) terendah ada di Kabupaten Nias Selatan (32,14\%), Kota Gunungsitoli (50,94\%), dan Kabupaten Nias Barat (59,0\%). (Profil Kesehatan Provinsi Sumatera Utara, 2019)

Menurut data yang diambil dari Riskesdas (2018) mengenai proporsi pelayanan masa nifas pada perempuan 10-54 tahun menurut Provinsi Sumatera Utara yaitu, 6 jam-3 hari (KF1) terdapat 93,1\% ; 4-28 hari (KF2) terdapat 58,7\% ; dan 29-42 hari (KF3) terdapat 18,6\% . (Riskesdas, 2018)

Diperkirakan ada 303.000 kematian ibu setiap tahunnya, menurut WHO (World Health Organization) baru-baru ini. Kebanyakan kematian ini terjadi setelah persalinan. Oleh karena itu, periode pasca kelahiran merupakan kesempatan penting untuk memperbaiki kesehatan dan kesejahteraan ibu dan sebelum kelahiran bayi: mendukung perilaku sehat, menyediakan pendidikan keterampilan hidup, memfasilitasi pemberian ASI kepada wanita tentang perencanaan keluarga, mendukung kesehatan mental yang baik, mencegah dan menangani komplikasi yang berkaitan dengan kelahiran anak. (WHO, 2020)

Angka kejadian post partum blues di Indonesia menurut USAID (United Stase Agency for International Development) (2016) terdapat 31 kelahiran per 1000 populasi. Indonesia menduduki peringkat keempat tertinggi di ASEAN setelah Laos yaitu sebanyak 26 kelahiran per 1000 populasi dan Kamboja yaitu sebanyak 25 kelahiran per 1000 populasi. Di Indonesia beberapa penelitian sudah dilakukan tentang post partum blues, menurut penelitian yang dilakukan oleh Edward (2017) angka kejadian post partum blues di Indonesia mencapai 23\%, sedangkan skrining dengan menggunakan EPDS didapatkan bahwa 14-17\% wanita post partum berisiko mengalami post partum blues. Tingginya angka kejadian post partum blues pada ibu pasca melahirkan dapat menimbulkan dampak yang signifikan terhadap keadaan psikologis ibu. 
Skrining untuk mendeteksi gangguan mood atau depresi merupakan acuan pelayanan pasca salin yang rutin dilakukan di luar negeri. Edinburg Postnatal Depression Scale yaitu kuesioner dengan validitas yang teruji yang dapat mengukur intensitas perubahan suasana perasaan selama 7 hari pasca salin.

Pertanyaan-pertanyaan berhubungan dengan labilitas perasaan, kecemasan, perasaan bersalah serta mencakup hal-hal yang terdapat dalam post partum blues. Kuesioner ini terdiri dari 10 pertanyaan dimana setiap pertanyaan memiliki 4 pilihan jawaban yang mempunyai nilai skor dan harus dipilih satu sesuai dengan gradasi perasaan yang dirasakan ibu pasca salin saat ini. Pertanyaan harus dijawab sendiri oleh ibu dan rata-rata dapat diselesaikan dalam waktu 5 menit. Alat ini telah teruji validitasnya di beberapa negara seperti Belanda, Swedia, Australia, Italia dan Indonesia.

Berdasarkan proporsi gangguan/komplikasi masa nifas pada perempuan umur 10-54 tahun menurut karakteristik di Provinsi Sumatera Utara, terdapat 10,17\% yang mengalami gangguan/komplikasi di masa nifas sedangkan angka kejadian Baby Blues/Post Partum Blues di Sumatera Utara yaitu sebanyak 0,76\%. (Riskesdas, 2018). Berdasarkan hasil penelitian yang dilakukan oleh Parida \& Desna (2018) mengenai Gambaran Pengetahuan Ibu Postpartum tentang Postpartum Blues di Klinik Sunggal Medan Tahun 2017, bahwa dari 13 orang responden yang diteliti mayoritas responden memiliki pengetahuan cukup sebanyak $7(53,8 \%)$ orang dan minoritas reponden memiliki pengetahuan kurang sebanyak 2 orang $(15,3 \%)$, serta sebanyak $4(30,8 \%)$ responden berpengetahuan baik.

Berdasarkan survei pendukung di BPM Juliana Muara Fajar Kecamatan Rumbai pada November 2020 bahwa terdapat 3 orang ibu nifas yang mengalami tanda dan gejala dari pada post partum blues. Pertama, ibu nifas 6 jam dengan keluhan tidak percaya diri dengan kelahiran anaknya yang ke-5 dikarenakan jumlah anak yang cukup banyak disertai dengan ekonomi keluarga yang minim sehingga takut tidak bisa memenuhi kebutuhan anak-anaknya. Kedua, ibu nifas 3 hari mengatakan cemas dan risau karena belum bisa memberikan ASI secara maksimal kepada bayinya karena ASI ibu belum keluar banyak. Ketiga, ibu nifas 1 minggu mengatakan merasa kurang maksimal dengan persalinannya, dikarenakan ibu belum bisa untuk melakukan proses persalinan normal.

Dikarenakan adanya wabah virus corona (covid-19) sampai saat ini, maka salah satu kebijakan pemerintah untuk belajar dirumah saja. Maka dari itu peneliti dapat melakukan penelitian di Kota Medan dan tidak dapat kembali ketempat penelitian awal yaitu di kampung halaman serta tetap melalukan social distancing dan safe healthy. Penelitian dilakukan pada Januari-April di Klinik Pratama SAM Kecamatan Medan Maimun Kota Medan Tahun 2021. Survei pendahuluan yang dilakukan oleh peneliti pada bulan Januari - Pertengahan Februari 2021 bahwa jumlah ibu bersalin sebanyak 29 orang. Beberapa diantaranya mengalami tanda dan gejala dari post partum blues tersebut, yaitu terdapat $12 \mathrm{ibu}$ bersalin dengan kehamilan yang tidak diinginkan (7 ibu bersalin dengan kejadian hamil diluar nikah dan 5 Ibu bersalin dengan alasan jumlah anak yang sudah banyak), 10 Ibu nifas dengan keluhan mengenai jumlah ASI yang sedikit, 3 ibu bersalin merasa sedih karena tidak didampingi oleh suaminya, dan 4 ibu dalam keadaan normal.

\section{Metode Penelitian}

Rancangan penelitian ini bersifat deskriptif, yang bertujuan untuk memaparkan gambaran karakteristik dan pengetahuan ibu nifas tentang Post Partum Blues pada ibu nifas. Populasi dalam penelitian ini yaitu difokuskan kepada seluruh ibu nifas yang bersalin di Klinik Pratama SAM Kecamatan Medan Maimun Tahun 2021. Jumlah Populasi yaitu sebanyak 20 orang ibu nifas yang bersalin ditempat. Sampel pada penelitian ini yaitu seluruh jumlah populasi yang dimana berjumlah 20 orang ibu nifas yang akan diteliti 


\section{Health Caring: Jurnal Illmiah Kesehatan}

Volume: 1 | Nomor 1 | Januari 2022 | E-ISSN: xxxx-Xxxx |

DOI: doi.org/healthcaring.v1n1.1251

di Klinik Pratama SAM Kecamatan Medan Maimun Tahun 2021. Teknik pengambilan sampel yaitu total samphling. Alat ukur yang digunakan untuk pengumpulan data pada penelitian ini adalah kuesioner dan berisi sejumlah pertanyaan-pertanyaan tertulis yang digunakan untuk mengukur pengetahuan ibu nifas tentang Post Partum Blues. Data yang sudah dikumpulkan kemudian dimasukkan kedalam program prangkat lunak SPSS untuk mengetahui distribusi frekuensinya. Lokasi penelitian ini yaitu di Klinik Pratama SAM Kecamatan Medan Maimun Tahun 2021. Penelitian dilaksanakan mulai dari tanggal 29 Maret 2021 sampai 30 April 2021.

\section{Hasil}

Tabel 1 Distribusi Frekuensi Karakteristik Ibu Nifas berdasarkan Umur, Paritas, Pendidikan di Klinik Pratama SAM Kecamatan Medan Maimun Tahun 2021

\begin{tabular}{lcc}
\hline No & Frekuensi (f) & Presentase (\%) \\
\hline 1. Umur & 1 & 5 \\
$\leq 20$ Tahun & 15 & 75 \\
20-35 Tahun & 4 & 20 \\
$\geq 35$ Tahun & $\mathbf{2 0}$ & $\mathbf{1 0 0}$ \\
\hline Total & 5 & 25 \\
\hline 2. Paritas & 10 & 50 \\
Primipara & 5 & 25 \\
Multipara & $\mathbf{2 0}$ & $\mathbf{1 0 0}$ \\
Grandemultipara & 3 & 15 \\
Total & 3 & 10 \\
\hline Pendidikan & 2 & 45 \\
SD & 9 & 30 \\
SMP & 6 & $\mathbf{1 0}$ \\
SMA & $\mathbf{2 0}$ & \\
Perguruan Tinggi & & \\
\hline Total & 5 & \\
\hline
\end{tabular}

\section{Sumber: Hasil Pengolahan Kuesioner, 2021.}

Berdasarkan hasil penelitian, bahwa Gambaran Karakteristik Umur Ibu Nifas tentang Post Partum Blues di Klinik Pratama SAM Kecamatan Medan Maimun Tahun 2021, mayoritas berumur 20-35 tahun sebanyak 15 orang $(75 \%)$.

Berdasarkan hasil penelitian, bahwa Gambaran Karakteristik Paritas Ibu Nifas tentang Post Partum Blues di Klinik Pratama SAM Kecamatan Medan Maimun Tahun 2021, mayoritas berdasarkan paritas yaitu multipara sebanyak 10 orang (55\%). 
Volume: 1 | Nomor 1 | Januari 2022 | E-ISSN: xxxx-xxxx |

DOI: doi.org/healthcaring.v1n1.1251

Berdasarkan hasil penelitian, bahwa Gambaran Karakteristik Pendidikan Ibu Nifas tentang Post Partum Blues di Klinik Pratama SAM Kecamatan Medan Maimun Tahun 2021, mayoritas berpendidikan terakhir yaitu SMA sebanyak 9 orang (45\%).

Tabel 2 Distribusi Frekuensi Pengetahuan Ibu Nifas tentang Post Partum Blues di Klinik Pratama SAM Kecamatan Medan Maimun Tahun 2021

\begin{tabular}{|c|c|c|c|}
\hline No & Pengetahuan & Frekuensi (f) & Persentase (\%) \\
\hline 1 & Kurang & 11 & 55 \\
\hline 2 & Cukup & 5 & 25 \\
\hline 3 & Baik & 4 & 20 \\
\hline
\end{tabular}

Sumber: Hasil Pengolahan Kuesioner, 2021.

Berdasarkan hasil penelitian, bahwa Gambaran Pengetahuan Ibu Nifas tentang Post Partum Blues di Klinik Pratama SAM Kecamatan Medan Maimun Tahun 2021, pengetahuan ibu tentang post partum blues mayoritas berpengetahuan kurang sebanyak 11 orang $(55 \%)$.

\section{Pembahasan}

\section{Gambaran Karakteristik Umur, Paritas dan Pendidikan Ibu Nifas tentang Post Partum Blues di} Klinik Pratama SAM Kecamatan Medan Maimun Tahun 2021

Berdasarkan hasil penelitian, distribusi responden berdasarkan umur adalah sebagai berikut, yaitu dari 20 orang terdapat responden yang berumur $\leq 20$ Tahun sebanyak 1 orang (5\%), berumur 20-35 tahun sebanyak 15 orang $(75 \%)$ dan berumur $\geq 35$ Tahun sebanyak 4 orang $(20 \%)$.

Penelitian ini sejalan dengan penelitian Anggrita Sari, dkk, mengenai umur pada ibu nifas yang dimana dari 57 responden yang ada, sebagian besar responden terbanyak adalah yang berumur antara 20-35 tahun berjumlah 48 orang $(84,2 \%)$. Dalam penelitian ini umur tidak terbukti membuat pengetahuan menjadi lebih baik, hal ini mungkin disebabkan karena adannya faktor lain yang dapat mempengaruhi pengetahuan yaitu sosial budaya dan lingkungan.

Usia merupakan satuan waktu yang mengukur waktu keberadaan makhluk hidup. Semakin cukup usia, tingkat kematangan dan kekuatan seseorang akan lebih matang dalam berpikir dan bekerja. Usia perempuan saat kehamilan dan persalinan seringkali dikaitkan dengan kesiapan mental perempuan tersebut untuk menjadi seorang ibu. Sebagian besar masyarakat percaya bahwa saat yang tepat bagi seseorang perempuan untuk melahirkan pada usia antara 20-30 tahun, dan hal ini menjadi optimal bagi perawatan bayi oleh seorang ibu. (Sloane, 2009)

Menurut (Notoatmojo, 2007) Semakin cukup umur tingkat kemampuan dan kekuatan seseorang akan lebih matang dalam berfikir maupun bekerja. Dari segi kepercayaan masyarakat, seseorang yang lebih dewasa akan dipercaya dari orang yang belum cukup umur. 
Asumsi peneliti mengenani umur tidak terbukti membuat pengetahuan menjadi lebih baik, hal ini mungkin disebabkan karena adannya faktor lain yang dapat mempengaruhi pengetahuan yaitu sosial budaya dan lingkungan, seperti halnya ibu yang mempunyai umur $<20$ tahun kurangnya informasi tentang post partum blues karena dari segi pengalamannya ibu nifas dengan umur $<20$ tahun adalah ibu nifas yang perlu menegtahui informasi tentang post partum blues.

Berdasarkan hasil penelitian dari 20 responden mengenai paritas menunjukkan bahwa jumlah keseluruhan ibu nifas primipara terdapat 5 orang (25\%), jumlah multipara 10 orang $(55 \%)$ dan jumlah grandemultipara 5 orang $(25 \%)$.

Penelitian ini sejalan dengan penelitian Irawati Naser, 2016, berdasarkan hasil penelitian didapatkan bahwa sebagian besar responden sudah mempunyai anak sebelumnya atau multipara dengan jumlah 33 orang $(60,0 \%)$.

Paritas adalah wanita yang pernah melahirkan bayi yang hidup (viable). Semakin banyak anak maka semakin banyak pengalaman seseorang dalam menjalani masa nifasnya. Pengalaman merupakan guru terbaik. Pepatah tersebut dapat diartikan bahwa pengalaman merupakan sumber pengetahuan, atau pengalaman itu suatu cara untuk memperoleh kebenaran pengetahuan. Jadi semakin banyak pengalaman (dalam hal ini paritas) semakin tinggi pula pengalaman yang diperoleh.

Salah satu faktor yang mempengaruhi pengetahuan adalah paritas. Paritas adalah jumlah anak yang dilahirkan oleh seorang wanita selama hidupnya, hal ini sangat mempengaruhi kesehatannya. Paritas 2-3 kali merupakan paritas paling aman ditinjau dari sudut kematian neonatal, sedangkan paritas tinggi yang lebih dari 4 mempunyai resiko angka kematian ibu lebih tinggi.Namun menurut asumsi peneliti, paritas tidak mempengaruhi post partum blues karena itu tergantung dari kesiapan emosi dan mental dari ibu itu sendiripra dan pasca partus. Selain itu dukungan dari lingkungan sekitar juga mempengaruhi perkembangan mental seseorang.

Menurut asumsi peneliti mengenai teori paritas bahwasannya semakin banyak anak maka pengalaman ibu dalam masa nifas akan semakin baik. Hal ini tidak sesuai dengan hasil penelitian yang telah dilakukan oleh peneliti yang dimana jumlah responden dengan berpengetahuan kurang mayoritasnya adalah multipara.

Berdasarkan hasil penelitian dari 20 responden mengenai pendidikan, terdapat ibu nifas berpendidikan SD 3 orang (15\%), berpendidikan SMP sebanyak 2 orang (10\%), SMA terdapat 9 orang (45\%) dan perguruan tingggi sebanyak 6 orang (30\%).

Penelitian ini sejalan dengan penelitian Anggrita Sari, dkk, di RSUD Dr. H. Moch. Ansari Saleh Banjarmasin, yaitu dari 57 orang responden sebagian besar pendidikan yang terbanyak adalah yaitu SMA 31 orang $(54,3 \%), 1$ orang $(3,1 \%)$ berpengetahuan baik 18 orang $(56,2 \%)$ berpengetahuan cukup 17 orang (40,7\%), berpengetahuan kurang. Sedangkan responden paling sedikit berpendidikan SD juga terdapat 4 orang $(7.02 \%), 3$ orang $(75 \%)$ berpengetahuan cukup dan 1 orang $(25 \%)$ berpengetahuan kurang.

Pendidikan merupakan proses perubahan sikap dan tata laku seseorang atau kelompok orang dalam usaha mendewasakan manusia melalui upaya pengajaran dan pelatihan. Perempuan yang berpendidikan tinggi akan menghadapi konflik peran, yaitu tuntutan sebagai perempuan yang memiliki pekerjaan diluar rumah. Antara berperan sebagai ibu rumah tangga saja atau melakukan pekerjaan diluar rumah dengan peran mereka juga sebagai ibu rumah tangga dan orang tua dari anak- anak mereka. Hal ini sangat berpengaruh pada konflik batin ibu tentang kekhawatiran kelanjutan kehidupan bayinya. 
Menurut (Notoatmojo, 2007) pendidikan berarti bimbingan yang diberikan seseorang terhadap perkembangan orang lain menuju kearah suatu cita-cita tertentu. Kegiatan pendidikan formal maupun informal berfokus pada proses belajar mengajar, dengan tujuan agar terjadi perubahan perilaku yaitu dari tidak tahu menjadi tahu, dari mengerti menjadi mengerti, dan dari tidak dapat menjadi dapat. Maka makin tinggi pendidikan seseorang makin mudah menerima informasi sehingga makin banyak pula pengetahuan yang dimiliki.

Menurut asumsi peneliti pendidikan seseorang seperti SD, SMP, SMA maupun Perguruan Tinggi tidak mempengaruhi pengetahuan seseorang terhadap post partum blues. Hal ini dipengaruhi karena pengetahuan tentang pengetahuan post partum blues tidak didapat dijenjang pendidkan formal, tetapi lebih banyak dari pelayanan kesehatan yang di dapatkan pada saat hamil. Hal ini tidak sesuai dengan teori yang telah dikemukakan diatas menunjukan bahwa pendidikan mempengaruhi proses belajar, semakin tinggi pendidikan cendrung semakin mudah orang tersebut untuk menerima informasi baik dari orang lain maupun media massa.

\section{Gambaran Pengetahuan Ibu Nifas tentang Post Partum Blues di Klinik Pratama SAM Kecamatan Medan Maimun Tahun 2021}

Berdasarkan hasil penelitian mengenai pengetahuan ibu nifas tentang Post Partum Blues di Klinik Pratama SAM Kecamatan Medan Maimun Tahun 2021 yang berpengetahuan kurang terdapat 11 orang (55\%), pengetahuan cukup 5 orang $(25 \%)$ dan pengetahuan baik 4 orang $(20 \%)$.

Penelitian ini sejalan dengan hasil penelitian yang dilakukan oleh Nova Rianti yang berjudul "Hubungan Karakteristik Ibu Nifas dengan Kejadian Post Partum Blues di Klinik Bersalin Bromo Medan Tahun 2018”. Pada penelitian ini didapatkan hasil bahwa ibu nifas berpengetahuan kurang dengan presentase $70 \%$ atau sebanyak 21 orang dari 30 orang responden.

Dalam penelitian yang lain, yaitu oleh Mariyatul Qiftiah yang berjudul Gambaran Faktor-faktor (Dukungan Keluarga, Pengetahuan, Status Kehamilan dan Jenis Persalinan) yang Melatarbelakangi Kejadian Post Partum Blues Pada Ibu Nifas Hari Ke-7 (Di Polindes Doa Ibu Gesikharjo dan Polindes Teratai Kradenan Palang) Tahun 2018. Pada penelitian ini juga didapatkan bahwa ibu nifas berpengetahuan kurang dengan presentase $42 \%$ atau sebanyak 10 orang dari 24 orang responden.

Pengetahuan adalah hasil "Tahu" yang terjadi setelah orang melakukan pengideraan terhadap suatu objek tertentu dan melalui panca indra manusia, yaitu: indra penglihatan, pendengaran, penciuman, rasa, dan raba. Tingkat pengetahuan terbagi dalam domain kognitif yang mempunyai enam tingkatan, yaitu tahu (know), memahami (comprehension), aplikasi (application), analisis (analysis), sintesis (synthesis), evaluasi (evaluation). Melalui tahapan tersebut inovasi dapat diterima maupun ditolak.

Pengetahuan adalah kesan di dalam pikiran manusia sebagai hasil penggunaan panca indranya. Sebagian besar pengetahuan itu sendiri dipengaruhi oleh tingkat pendidikan, dimana pengetahuan kesehatan akan berpengaruh kepada perilaku sebagai hasil jangka menengah (intermediate impact) oleh reaksi emosional atau kepercanyaan mengenai apa yang dianggap benar tentang sesuatu objek dipilih. Tidak ada pengalaman sama sekali dengan suatu objek, pengaruh orang lain yang dianggap penting dalam kehidupan sosial sangat berpengaruh dalam pembentukan sikap.

Asumsi peneliti berdasarkan hasil penelitian, yang dimana bila dikaitkan dengan pengetahuan responden bahwa lebih banyak responden memiliki pengetahuan yang kurang tentang post partum blues. 
Pengetahuan yang diharapkan adalah pengetahuan yang baik. Hal ini disebabkan kurangnya keingintahuan ibu post partum tentang post partum blues, kurangnya informasi pada responden sehingga dapat mempengaruhi ilmu pengetahuan responden yang masih rendah, umur responden yang terlalu muda untuk menikah sehingga kurangnya persiapan dalam menyambut kelahiran bayi baik secara fisik maupun mental serta tingkat pendidikan dan tidak memiliki pekerjaan yang membuat ibu postpartum sulit untuk mendapatkan informasi yang lebih khususnya tentang post partum blues

Maka dilakukan usaha untuk meningkatkan pengetahuan ibu nifas tentang post partum blues yang dimulai dari bidan, petugas kesehatan atau kerabat dekat yang sangat dibutuhkan informasi tentang post partum blues, sehingga perlu adanya upaya promotif untuk semua ibu nifas yang dapat mulai diinformasikan sejak hamil dengan melakukan penyuluhan tentang post parum blues. Berfokus pada proses belajar mengajar, dengan tujuan agar terjadi perubahan perilaku yaitu dari tidak tahu menjadi tahu dan dari tidak mengerti menjadi mengerti.

\section{Kesimpulan}

Dari hasil penelitian yang telah dilakukan terhadap Gambaran Karakteristik dan Pengetahuan Ibu Nifas tentang Post Partum Blues di Klinik Pratama SAM Kecamatan Medan Maimun Tahun 2021. Dan pengolahan data yang dilakukan, dapat.diambil kesimpulan sebagai berikut:

1. Berdasarkan hasil penelitian, bahwa Gambaran Pengetahuan Ibu Nifas tentang Post Partum Blues di Klinik Pratama SAM Kecamatan Medan Maimun Tahun 2021, pengetahuan ibu tentang post partum blues mayoritas berpengetahuan kurang sebanyak 11 orang (55\%) dan minoritas berpengetahuan baik sebanyak 4 orang $(20 \%)$.

2. Berdasarkan hasil penelitian, bahwa Gambaran Karakteristik Umur Ibu Nifas tentang Post Partum Blues di Klinik Pratama SAM Kecamatan Medan Maimun Tahun 2021, mayoritas berumur 20-35 tahun sebanyak 15 orang (75\%) dan minoritas berumur $\leq 20$ tahun sebanyak 1 orang (5\%). Berdasarkan hasil penelitian, bahwa Gambaran Karakteristik Paritas Ibu Nifas tentang Post Partum Blues di Klinik Pratama SAM Kecamatan Medan Maimun Tahun 2021, mayoritas berdasarkan paritas yaitu multipara sebanyak 10 orang $(55 \%)$ dan minoritas yaitu Primipara sebanyak 5 orang (25\%) dan Grandemultipara sebanyak 5 orang (25\%). Berdasarkan hasil penelitian, bahwa Gambaran Karakteristik Pendidikan Ibu Nifas tentang Post Partum Blues di Klinik Pratama SAM Kecamatan Medan Maimun Tahun 2021, mayoritas berpendidikan terakhir yaitu SMA sebanyak 9 orang $(45 \%)$ dan minoritas berpendidikan terakhir yaitu SMP sebanyak 2 orang (10\%).

\section{Referensi}

Anggrita Sari, dkk. 2015. Gambaran Pengetahuan Ibu Nifas tentang Post Partum Blues di RSUD Dr. H. Moch. Ansari Saleh Banjarmasin. Dinamika Kesehatan.

Hanum, Parida; Desna Verayanti. (2018). Gambaran Pengetahuan Ibu Postpartum Tentang Postpartum Blues Di Klinik Sunggal Tahun 2017. Jurnal Maternitas Kebidanan, 3 (1), 1-7.

Naser, Irawati. 2016. Gambaran Tingkat Pengetahuan Ibu Nifas tentang Tanda Bahaya Masa Nifas di RSUD SlemanYogyakarta. 


\section{Health Caring: Jurnal Illmiah Kesehatan}

Volume: 1 | Nomor 1 | Januari 2022 | E-ISSN: xxxx-Xxxx |

DOI: doi.org/healthcaring.v1n1.1251

Profil Kesehatan Provinsi Sumatera Utara, 2019

Pulungan, P. (2020). Teori Kesehatan Reproduksi. In Yayasan Kita Menulis (p. 178). Yayasan Kita Menulis.

Qiftiyah, Mariyatul. 2018. Gambaran Faktor-Faktor (Dukungan Keluarga, Pengetahuan, Status Kehamilan dan Jenis Persalinan) yang Melatarbelakangi Kejadia Post Partum Blues pada Ibu Nifas Hari ke-7.

Rianti, Nova. 2018. Hubungan Karakteristik Ibu Nifas dengan Kejadian Post Partum Blues di Klinik Bersalin Bromo Medan Tahun 2018.

Rini, S. \& F. K. D. (2017). Panduan Asuhan Nifas dan Evidence Based Practice. In Panduan Asuhan Nifas dan Evidence Based Practice (p.272). Deepublish.

Riset Kesehatan Dasar (Riskesdas). (2018). Badan Penelitian dan Pengembangan Kesehatan Kementerian RI tahun 2018. Diakses: 27 Desember 2018 dari www.depkes.go.id

Sri Wahyuningsih \& Mahasiswi D3 Keperawatan. 2019. Buku Ajar Asuhan Keperawatan Post Partum. Yogyakarta: Deepublish.

United Stase Agency for International Development. 2016. Facts for Family Planning. Washington, DC: USAID

Viva, Yuanita. 2020. Faktor-Faktor Yang Berhubungan Dengan Pengetahuan Ibu Hamil tentang IMD di Bidan E Kabupaten Bogor. Jurnal Kesehatan Karya Husada. 